\title{
Keratopathy, cataract, and dry eye in a survey of aniridia subjects
}

\author{
This article was published in the following Dove Press journal: \\ Clinical Ophthalmology \\ 10 February 2015 \\ Number of times this article has been viewed
}

\section{David Shiple' \\ Brenton Finklea' \\ James D Lauderdale ${ }^{2}$ \\ Peter A Netland' \\ 'Department of Ophthalmology, University of Virginia School of Medicine, Charlottesville, VA, USA; ${ }^{2}$ Department of Cellular Biology, University of Georgia, Athens, GA, USA}

\begin{abstract}
Purpose: To determine the prevalence of keratopathy, cataract, and dry eye in a group of individuals with aniridia.

Methods: We reviewed survey data from the Aniridia Foundation International (AFI) registry, which included 99 subjects who self-reported on corneal disease, cataract, and dry eye disease.

Results: The average age of respondents was $25.3 \pm 18.6$ years, with a range of 0 to 67 . Of 99 subjects, $46 \%$ stated they have corneal disease, $32 \%$ stated they did not, and $22 \%$ were unsure. The average age of diagnosis of keratopathy was $20.0 \pm 12.2$ years. Keratolimbal allograft was reported in $20 \%$ and penetrating keratoplasty in $9 \%$. Cataract was reported in $65 \%$, with an average age of $9.4 \pm 14.0$ years at time of diagnosis, and cataract surgery was reported in $32 \%$. The average age of subjects at the time of cataract and corneal surgery was $28.4 \pm 13.7$ and $33.5 \pm 11.4$ years, respectively. Symptomatic dry eye was reported in $56 \%$ of subjects, with an average age at diagnosis of $23.8 \pm 13.3$ years.

Conclusion: There is a high prevalence of corneal disease in aniridia, with diagnosis in late childhood or early adulthood in nearly one-half of subjects, often requiring corneal surgery. Cataract and dry eye are commonly associated with aniridia. Although aniridia subjects may have been aware of the diagnosis of cataract at an early age, they usually were treated for cataract and keratopathy as adults.
\end{abstract}

Keywords: aniridic keratopathy, ocular surface disease, corneal disease, keratolimbal allograft

\section{Introduction}

Aniridia is a rare congenital hypoplasia of the iris, which is a bilateral, panocular abnormality affecting the iris, anterior chamber angle, cornea, lens, and retina over the course of a patient's lifetime. ${ }^{1,2}$ Visual dysfunction in aniridia may be due to multiple abnormalities, including corneal disease, glaucoma, foveal hypoplasia, and cataract formation. The condition is associated with a mutation in the $P A X 6$ gene on band $\mathrm{p} 13$ of chromosome 11, 1,3 and larger deletions may be associated with abnormality of the Wilms tumor (WT1) gene. ${ }^{4}$ Aniridia-associated keratopathy is progressive with age and may cause pain and discomfort as well as visual impairment.

The pathogenesis of aniridic keratopathy has been attributed to congenital limbal stem cell deficiency, though this presumption has been made based on clinical and histopathologic features rather than demonstration of deficiency of stem cells. ${ }^{5}$ In vivo confocal microscopy has indicated loss of limbal palisades of Vogt in some but not all patients with early aniridic keratopathy, suggesting that stem cells may not be absent in all cases. ${ }^{6}$ Progression of aniridic keratopathy has correlated with degradation of palisade structures, gradual transformation of epithelial phenotype, onset of inflammation, and loss of corneal nerves. ${ }^{7}$ Aniridic keratopathy is associated with
Correspondence: Peter A Netland University of Virginia School of Medicine, PO Box 8007I5, Charlottesville, VA 22908-07I5, USA

Tel + I 4349821086

Fax + I 4349245180

Email pnetland@virginia.edu 
abnormal corneal epithelial healing response ${ }^{8-10}$ and may be exacerbated by trauma. ${ }^{11}$ Both corneal disease and cataract have previously been found to occur at high prevalence in individuals affected with aniridia. ${ }^{12}$

In a previous study, we evaluated the ocular and systemic abnormalities associated with aniridia, including an analysis of prevalence of glaucoma in this population. ${ }^{12}$ In addition, we found increased average body mass index and prevalence of overweight and obesity, which appeared to occur not only in WAGR syndrome but more broadly in aniridia. The purpose of this study was to evaluate the occurrence of keratopathy, cataract, and dry eye in a group of aniridia subjects. We also intended to analyze the prevalence of keratopathy and cataract with age in these subjects with aniridia.

\section{Subjects and methods}

This was a descriptive case series based on a survey of individuals with aniridia who are members of the Aniridia Foundation International (AFI). Survey forms were sent to potential subjects, and completed survey forms were collected from all individuals who attended conferences in 2007, 2009, and 2011. The survey protocol was approved by the institutional review board of the University of Virginia and followed the tenets of the Declaration of Helsinki and the requirements of the US Health Insurance Portability and Accountability Act. Informed consent was obtained from participants before their enrollment. The survey forms, developed by AFI, included a survey for the subjects to fill out and an additional form for information from physicians caring for the subject. The survey methods have been reported previously. ${ }^{12}$ Subjects provided all information on the survey forms; if they were minors, their parents provided the information. AFI staff and members assisted participants who had difficulty completing the forms.

Survey materials were assigned a coded number to protect the identity of the subject. Data were then reviewed by additional physician reviewers, who were masked to the identity of the patients. The survey provided to members of AFI included questions pertaining to the age at diagnosis of aniridia, corneal disease, corneal surgical treatments, cataract, and dry eyes. The cumulative proportion of subjects with keratopathy and cataract versus age was calculated. Data about the subject's age, sex, self-identified race, and type of aniridia (sporadic or familial) was collected, and information about ocular abnormalities was reviewed. Dry eye was self-reported as diagnosed by an ophthalmologist. Subjects were asked about the age at diagnosis of ocular abnormalities, as well as current and past ocular medical
Table I Characteristics of subjects

\begin{tabular}{ll}
\hline Characteristics & Subjects $\mathbf{( N = 9 9 )}$ \\
\hline Age at time of survey & \\
Mean \pm SD (years) & $25.3 \pm 18.6$ \\
Range (years) & $0-67$ \\
Age at time of diagnosis & \\
Mean \pm SD (years) & $3.3 \pm 6.5$ \\
Range (years) & $0-44$ \\
Sex, $n$ (\%) & \\
Male & $35(35.4)$ \\
Female & $64(64.6)$ \\
Race, $n$ (\%) & \\
Caucasian & $87(87.9)$ \\
African-American & $3(3.0)$ \\
Asian & $7(7.1)$ \\
Hispanic & $4(4.0)$ \\
Heredity, $n$ (\%) & \\
Familial & $34(34.3)$ \\
Sporadic & $57(57.6)$ \\
Unsure & $8(8.1)$ \\
\hline
\end{tabular}

Abbreviation: SD, standard deviation.

and surgical treatments. Means, standard deviations, and the cumulative proportion of subjects were calculated using Microsoft Excel.

\section{Results}

In total, 185 AFI surveys were sent to potential subjects; 108 returned the forms (58.4\% response rate), and 99 subjects self-reported information about corneal disease, cataract, and dry eye (91.7\% completion rate). Characteristics of the 99 subjects included in the study are shown in Table 1. The majority of subjects had sporadic aniridia (58\%), with $34 \%$ familial and $8 \%$ unsure. Table 2 shows the prevalence of corneal disease and cataract in aniridic subjects. A high

Table 2 Keratopathy and cataract in aniridic subjects

\begin{tabular}{lll}
\hline & $\begin{array}{l}\text { Keratopathy } \\
(\mathbf{N}=99)\end{array}$ & $\begin{array}{l}\text { Cataract } \\
\mathbf{( N = 9 9 )}\end{array}$ \\
\hline $\begin{array}{l}\text { Diagnosis, n (\%) } \\
\text { Yes }\end{array}$ & $45(45.5)$ & $64(64.6)$ \\
No & $32(32.3)$ & $28(28.3)$ \\
$\quad$ Unsure & $22(22.2)$ & $7(7.1)$ \\
Age at diagnosis & & \\
$\quad \begin{array}{l}\text { Mean } \pm \text { SD (years) } \\
\text { Range (years) }\end{array}$ & $20.0 \pm 12.2$ & $9.4 \pm \mid 4.0$ \\
$\begin{array}{l}\text { Surgery } \\
\text { N (\%) }\end{array}$ & $0-53$ & $0-50$ \\
$\begin{array}{l}\text { Age at surgery, } \\
\text { mean } \pm \text { SD (years) }\end{array}$ & $20(20.2)^{\mathrm{a}}$ & $32(32.3)$ \\
$\begin{array}{l}\text { Age at surgery, } \\
\text { range (years) }\end{array}$ & $33.5 \pm \mid 1.4$ & $28.4 \pm \mid 3.7$ \\
\hline
\end{tabular}

Note: aKeratolimbal allograft was reported in 20 subjects, with additional penetrating keratoplasty in nine of these 20 subjects.

Abbreviation: SD, standard deviation. 


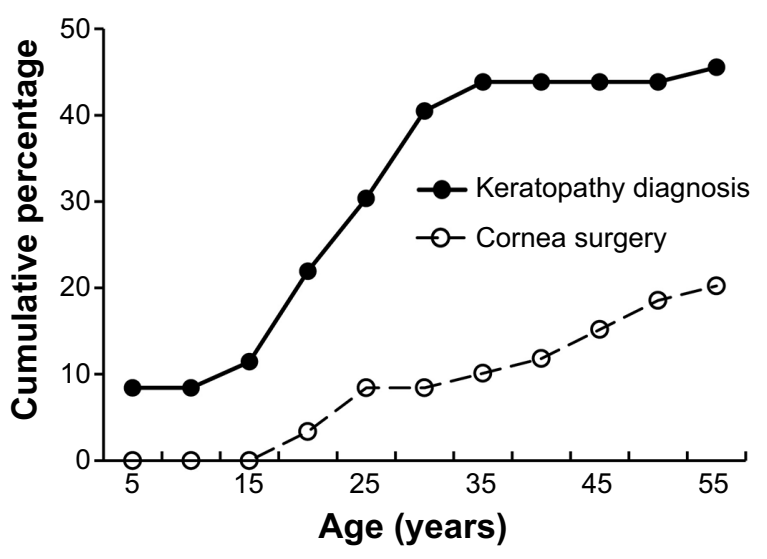

Figure I Cumulative percentage of aniridic subjects reporting corneal disease and treatment with corneal surgery.

proportion of subjects reported keratopathy and cataract $(46 \%$ and $65 \%$, respectively). Diagnosis of cataract occurred at median age 3 years and mean age $9.4 \pm 14.0$ years, while the average age of cataract surgery was $28.4 \pm 13.7$ years. Diagnosis of keratopathy occurred at median age 20.5 years and mean age $20.0 \pm 12.2$ years, while the average age of corneal surgery was $33.5 \pm 11.4$ years. Of the 99 subjects diagnosed with aniridia, 20 of $99(20 \%)$ had been treated with keratolimbal allograft (KLAL), while nine of these 20 subjects $(9 \%)$ were also treated with penetrating keratoplasty (PK). Of those who received both PK and KLAL, seven of 99 (7.1\%) reported PK after KLAL, and two of 99 (2.0\%) had PK prior to KLAL. Figure 1 shows the cumulative percentage of aniridic patients diagnosed with keratopathy and treated with cornea surgery. Figure 2 shows the cumulative percentage of aniridic subjects diagnosed with cataract and treated with cataract surgery. Dry eye was reported in 55 of 99 subjects (56\%). Diagnosis of dry eye occurred at median age 22.0 years and mean age $23.8 \pm 13.3$ years. The average

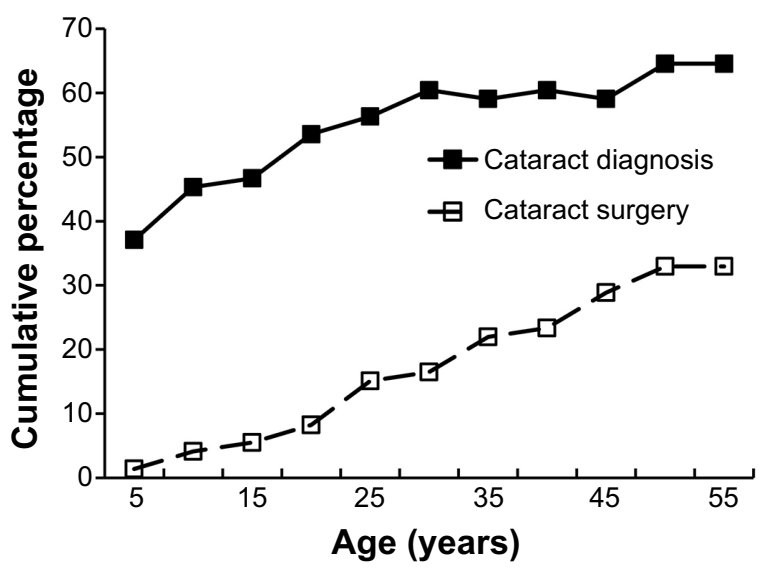

Figure 2 Cumulative percentage of aniridic subjects reporting cataract and treatment with cataract surgery. age of diagnosis of dry eye was not significantly different compared with the average age of diagnosis of keratopathy $(P=0.141)$.

\section{Discussion}

In this study, we found a high prevalence of corneal disease in individuals with aniridia, reported by subjects in late childhood or early adulthood, with approximately one-half of those reporting keratopathy requiring corneal surgical treatment. Additionally, a high rate of dry eye was reported, which may affect the ocular surface in affected patients, compounding problems with aniridic keratopathy. The cause of visual impairment is multifactorial in aniridia, with a high prevalence of cataract exacerbating this problem in affected individuals.

We found a $46 \%$ prevalence of keratopathy reported by patients in our study. This is a lower value than direct observational studies have demonstrated, with reported prevalence of keratopathy ranging up to $98 \%$ to $100 \%{ }^{13,14}$ Aniridic keratopathy is progressive and has insidious onset, not affecting the vision of the patient until later stages of the disease. Grading of aniridic keratopathy was proposed by López-García et al in 2006, ${ }^{9}$ describing three phases of keratopathy distinguished by progressively increasing erosions, formation of a vascular pannus, and other signs and symptoms. In one study, up to $90 \%$ of eyes had some degree of corneal changes, while only $26 \%$ had visually significant keratopathy. ${ }^{11}$ Stages of keratopathy are characterized by increasing conjunctival appearance of the corneal surface, ${ }^{6,7}$ which may not be accurately reported by patients during the early manifestation of aniridic keratopathy.

In addition to underreporting of asymptomatic or undiagnosed keratopathy by subjects, another possible explanation for our lower value for reported keratopathy is the age of the subjects, with a mean age of 25 years at the time of survey. In an observational study, the prevalence of aniridic keratopathy was $60 \%$ in subjects under 10 years old, while there was $100 \%$ prevalence in subjects 41 years old and older. ${ }^{13}$ The lower rate of reporting compared with observational studies and the "unsure" responses suggest that the awareness of this problem can be improved.

KLALs have been used as a treatment to reduce the progression of aniridic keratopathy. ${ }^{15}$ Patients with aniridia have been treated with PK, although, without KLAL, grafts are highly prone to recurrence of keratopathy and graft failure. ${ }^{16,17}$ Due to the high rate of graft failure in PK, surgeons may attempt to repopulate limbal stem cells with KLAL prior to corneal transplant. In our study, patients who were treated with PK were more commonly treated with KLAL prior to 
PK. Individuals in our study were not asked to report on the use of keratoprosthesis; however, aniridic keratopathy has been treated effectively using this approach. ${ }^{18}$ A multicenter study showed long-term visual improvement in 14 of 15 aniridic patients after implantation of keratoprosthesis. ${ }^{19}$

In our study, cataract was reported in $65 \%$ of subjects, which falls within the reported range of $50 \%-85 \% .^{2,20}$ It is likely that the results of our study underestimate the actual incidence of lens disease in our participants, due to both patient unawareness of congenital or early acquired cataract and the young mean age of our subjects. Eye-care providers may not inform patients of visually insignificant or early cataract. In our study, patients were diagnosed with lens opacities at median age 2 years, but were treated with cataract surgery later in life, likely after further progressive changes in cataract. In direct observational studies, $69.8 \%$ of all subjects ${ }^{20}$ and $40.3 \%$ of phakic subjects ${ }^{21}$ with aniridia were found to have cataracts. Progressive changes of lens opacities have been described in aniridia patients, which predominantly affect the posterior subcapsular region. ${ }^{22}$

Diagnosis of dry eye was reported in $56 \%$ of our subjects. A previous study has demonstrated that the majority of aniridics experience moderate-to-severe dry eyes, and have correlated severity of dry eyes with severity of corneal surface disease. ${ }^{23}$ By comparison, in the general population, the prevalence of dry eye is approximately $12 \%$ in males and $22 \%$ in females. ${ }^{24}$ The problems with the ocular surface are multifactorial in aniridia, with dry eye likely exacerbating the keratopathy in many aniridic patients. In our study, the average age of diagnosis of dry eye and keratopathy was not significantly different, indicating that aniridia patients usually become aware of both of these diagnoses during early adulthood. While this finding suggests an association of these conditions, we were unable to determine the relationship between dry eye and keratopathy in this study.

This study is limited by the self-reporting method of data collection, with subjects potentially under- or overreporting problems. Pathology may be underreported, subjects may not be aware of the difference between various ocular problems, and subjects may not recall the timing or types of treatments. In order to improve accuracy of data collected, we provided assistance to subjects with completing the forms. With this limitation in mind, our study shows the prevalence of selfreported corneal disease, dry eye, and cataract in aniridia. Individuals with aniridia who are affected with corneal disease usually become aware of this problem in early adulthood, and are treated for corneal problems during their adult years.
The lower rate of self-reporting compared with observational studies suggests that awareness of corneal disease could be improved in this population. Also, cataract and dry eye were reported by the majority of our subjects, which indicates that multiple problems may influence visual function and the ocular surface in this population. Aniridia patients may be aware of cataracts at an early age, but are not treated, on average, until they are adults. The analysis of the cumulative percentage of aniridic patients diagnosed with and treated for corneal problems and cataract at different ages provides information that may be helpful to both patients and clinicians.

\section{Acknowledgments}

This study was supported in part by Aniridia Foundation International and the Sharon Stewart Trust.

\section{Disclosure}

The authors report no conflicts of interest in this work. The authors have no proprietary interest in this material.

\section{References}

1. Prosser J, van Heyningen V. PAX6 mutations reviewed. Hum Mutat. 1998;11:93-108.

2. Nelson LB, Spaeth GL, Nowinski TS, Margo CE, Jackson L. Aniridia. A review. Surv Ophthalmol. 1984;28:621-642.

3. Gehring WJ. The master control gene for morphogenesis and evolution of the eye. Genes Cells. 1996;1:11-15.

4. Fantes JA, Bickmore WA, Fletcher JM, Ballesta F, Hanson M, van Heyningen V. Submicroscopic deletions at the WAGR locus, revealed by nonradioactive in situ hybridization. Am J Hum Genet. 1992;51:1286-1294.

5. Dua HS, Azuara-Blanco A. Limbal stem cells of the corneal epithelium. Surv Ophthalmol. 2000;44:415-425.

6. Edén U, Fagerholm P, Danyali R, Lagali N. Pathologic epithelial and anterior corneal nerve morphology in early-stage congenital aniridic keratopathy. Ophthalmology. 2012;119:1803-1810.

7. Legali N, Edén U, Utheim TP, et al. In vivo morphology of the limbal palisades of Vogt correlates with progressive stem cell deficiency in aniridia-related keratopathy. Invest Ophthalmol Vis Sci. 2013;54: 5333-5342.

8. Ramaesh K, Ramaesh T, Dutton GN, Dhillon B. Evolving concepts on the pathogenic mechanisms of aniridia related keratopathy. Int J Biochem Cell Biol. 2005;37:547-557.

9. López-García JS, García-Lozano I, Rivas L, Martínez-Garchitorena J. [Congenital aniridia keratopathy treatment]. Arch Soc Esp Oftalmol. 2006;81:435-444. Spanish.

10. Collinson JM, Chanas SA, Hill RE, West JD. Corneal development, limbal stem cell function, and corneal epithelial cell migration in the Pax6(+/-) mouse. Invest Ophthalmol Vis Sci. 2004;45:1101-1108.

11. Edén U, Riise R, Tornqvist $\mathrm{K}$. Corneal involvement in congenital aniridia. Cornea. 2010;29:1096-1102.

12. Netland PA, Scott ML, Boyle JW 4th, Lauderdale JD. Ocular and systemic findings in a survey of aniridia subjects. $J$ AAPOS. 2011;15:562-566.

13. Mayer KL, Nordlund ML, Scwartz GS, Holland EJ. Keratopathy in congenital aniridia. Ocul Surf. 2003;1:74-79.

14. Nishida K, Kinoshita S, Ohashi Y, Kuwayama Y, Yamamoto S. Ocular surface abnormalities in aniridia. Am J Ophthalmol. 1995;120:368-375. 
15. Holland EJ, Djalilian AR, Schwartz GS. Management of aniridic keratopathy with keratolimbal allograft: a limbal stem cell transplantation technique. Ophthalmology. 2003;110:125-130.

16. Gomes JA, Eagle RC Jr, Gomes AK, Rapuano CJ, Cohen EJ, Laibson PR. Recurrent keratopathy after penetrating keratoplasty for aniridia. Cornea. 1996;15:457-462.

17. Kremer I, Rajpal RK, Rapuano CJ, Cohen EJ, Laibson PR. Results of penetrating keratoplasty in aniridia. Am J Ophthalmol. 1993;115: 317-320.

18. Aldave AJ, Kamal KM, Vo RC, Yu F. The Boston type I keratoprosthesis: improving outcomes and expanding indications. Ophthalmology. 2009;116:640-651.

19. Akpek EK, Harissi-Dagher M, Petrarca R, et al. Outcomes of Boston keratoprosthesis in aniridia: a retrospective multicenter study. Am J Ophthalmol. 2007;144:227-231.
20. Hingorani M, Williamson KA, Moore AT, van Heyningen V. Detailed ophthalmologic evaluation of 43 individuals with PAX6 mutations. Invest Ophthalmol Vis Sci. 2009;50:2581-2590.

21. Singh B, Mohamed A, Chaurasia S, et al. Clinical manifestations of congenital aniridia. J Pediatr Ophthalmol Strabismus. 2014;51:59-62.

22. Edén U, Lagali N, Dellby A, et al. Cataract development in Norwegian patients with congenital aniridia. Acta Ophthalmol. 2014;92: e165-e167.

23. Jastaneiah S, Al-Rajhi AA. Association of aniridia and dry eyes. Ophthalmology. 2005;112:1535-1540.

24. Galor A, Feuer W, Lee DJ, et al. Prevalence and risk factors of dry eye syndrome in a United States veterans affairs population. Am J Ophthalmol. 2011;152:384.
Clinical Ophthalmology

\section{Publish your work in this journal}

Clinical Ophthalmology is an international, peer-reviewed journal covering all subspecialties within ophthalmology. Key topics include: Optometry; Visual science; Pharmacology and drug therapy in eye diseases; Basic Sciences; Primary and Secondary eye care; Patien Safety and Quality of Care Improvements. This journal is indexed on

Submit your manuscript here: http://www.dovepress.com/clinical-ophthalmology-journal

\section{Dovepress}

PubMed Central and CAS, and is the official journal of The Society of Clinical Ophthalmology (SCO). The manuscript management system is completely online and includes a very quick and fair peer-review system, which is all easy to use. Visit http://www.dovepress.com/ testimonials.php to read real quotes from published authors. 